Marica Ž. Travar

Pedagoški fakultet u Bijeljini,

Republika Srpska, Bosna i Hercegovina

Pero M. Spasojević doi: 10.19090/zop.2018.27.151-172

UDC: $159.953 .5-053.4$

373.2:159.953.5

Originalni naučni rad

\title{
STAVOVI RODITELJA PREDŠKOLSKE DJECE O RANOM UČENJU*
}

\begin{abstract}
Apstrakt: Imajući u vidu pedagoški značaj uticaja sredine na rast i razvoj djece u ranom djetinjstvu najčešće se, kao ključni faktori, navode porodica i institucije za predškolsko vaspitanje i obrazovanje. U ovom radu autori se bave više djelovanjem porodice budući da se među roditeljima vrlo često uviđaju pogrešna uvjerenja o mogućnostima ranog učenja uopšte. Nepovjerenje roditelja u mogućnosti djelovanja na rast i razvoj ranim učenjem mogu biti pod uticajem različitih socio-demografskih varijabli, kulture obilježene tradicionalizmom i uopšte nasljeđem kulturnih obrazaca porodice iz prošlosti. S ciljem utvrđivanja stavova roditelja o ranom učenju, realizovali smo istraživanje na uzorku 150 roditelja čija djeca pohađaju vrtić - kako bismo identifikovali njihove stavove o ovom pitanju. Primijenjena metodologija odnosila se na otkrivanje razlika u stavovima roditelja o ranom učenju $\mathrm{s}$ obzirom na neka njihova socio-demografska obilježja koja su pod snažnim dejstvom kulturnog programa sredine. Rezultati istraživanja pokazali su da razlike u stavovima roditelja predškolske djece o ranom učenju - s aspekta pola, broja članova porodice, broja djece u porodici, redoslijeda rođenja djeteta u porodici i nivoa obrazovanja roditelja - nisu statistički značajne na ispitivanom uzorku. Dobijeni rezultati istraživanja upućuju na nekoliko važnih pedagoških implikacija koje su prikazane u radu.
\end{abstract}

Ključne riječi: rano učenje, stavovi roditelja, pedagoške implikacije.

\section{UVOD}

Porodica je, bez svake sumnje, institucija koja prva djeluje na dječiji razvoj i učenje, s obzirom na to da se dijete u njoj rađa, provodi prve godine života i stiče najranija iskustva. Ona je u svakom pogledu prva „sudbinska“, sigurna i stabilna sredina koja djeluje na rast i razvoj intuitivno, nasleđivanjem kulturnih obrazaca sredine, znanjem i iskustvom ili u bliskoj povezanosti sa profesionalcima u dječijim vrtićima. Posmatrajući porodicu iz

\footnotetext{
*Marica Travar, maricac86@gmail.com
} 
perspektive savremenih društvenih odnosa, zasigurno bi joj trebalo posvetiti daleko više pažnje u naučnim radovima i razvojnim projektima jer se u njoj odvija proces primarne socijalizacije čiji su dometi, po svemu sudeći, ipak presudni i djelotvorni na sve kasnije faze vaspitanja i obrazovanja. Dakle, riječ je o komplementarnom uticaju vrtića i porodice na ukupan rast i razvoj djeteta, na efekte ranog učenja u složenom sistemu vaspitanja, obrazovanja i cjeloživotnog učenja.

Predškolsko djetinjstvo je u postojećim naučnim izvorima i zahvaljujući savremenim istraživanjima u oblasti pedagogije i psihologije ocijenjeno kao zlatno doba za razvoj (Kamenov i Spasojević, 2008) a rano učenje kao jedan od najaktuelnijih izazova savremene pedagogije (Spasojević, Jeftović i Cvjetković, 2013). U vezi s tim, javlja se potreba preispitivanja postojećih praktičnih rješenja i modela za rano učenje $u$ porodici, jer porodica postaje sve važnija i odgovornija za razvoj djece budući da veliki broj predškolaca u našoj zemlji ne pohađa vrtić. U Strategiji razvoja obrazovanja Republike Srpske za period 2016-2021 postoji podatak da se obuhvat djece institucionalnim predškolskim vaspitanjem i obrazovanjem u našoj zemlji, zabilježen 2013/2014. godine, kreće između $4 \%$ i $29 \%$, zavisno od lokalne sredine. Iako više zasnovana na intuiciji, porodica je u svojim vaspitnim uticajima odgovorna i u stanju je da kreira kvalitetan učeći ambijent i tako doprinese napredovanju djece u svim aspektima razvoja. Međutim, uticaj porodice na rani dječiji rast i razvoj u velikoj mjeri zavisi od stavova koje roditelji imaju o ranom učenju. Otežavajuća okolnost u pogledu uticaja porodice na djecu ogleda se u tome da postoje dokazi da se protokom vremena smanjuje interesovanje roditelja za svoju djecu. U jednoj kanadskoj studiji utvrđeno je da trećina ispitivanih 
roditelja ima optimalan pristup roditeljstvu, ali vremenom njihova usmjerenost na djecu opada (Drummond, 2005). Ipak, važnost roditelja u procesu ranog učenja ne može se nadomjestiti ni najidealnijim fizičkim okruženjem za učenje. To su potvrdili roditelji i vaspitači, učesnici u jednoj kvalitativnoj studiji koja je imala za cilj da utvrdi kako ovi ispitanici procjenjuju važnost fizičkog okruženja za proces ranog učenja. Oni su ukazali da je fizičko okruženje važno za rano učenje i razvoj djeteta, ali je u ovom procesu ipak najvažniji uticaj ljudskog faktora (Berris \& Miller, 2011). Drugim riječima, dobre profesionalce u vrtićima ništa ne može zamijeniti, ali sve više postaje „nužno“ aktivno podržavanje roditelja i izgradnja njihovih kompetencija, upoznavanje i usvajanje njima primjerenih metoda kojima mogu postati dio jedinstvenog vaspitno-obrazovnog procesa.

Kakve će uslove porodica omogućiti za rano učenje i razvoj, odnosno kako će se u životnom ambijentu ponašati prema svom predškolcu, u velikoj mjeri zavisi od stavova koje roditelji imaju prema ranom učenju. U jednom od istraživanja sprovedenih u Hrvatskoj utvrđeno je da su socio-demografska obilježja značajna za formiranje roditeljskog ponašanja prema predškolskoj djeci. Broj djece u porodici pokazao se kao važan prediktor roditeljskog pozivitnog/negativnog ponašanja prema djeci, što važi i za starost majke (Štironja Borić, Roščić, Sedmak, Šepčević \& Keresteš, 2011). U istom istraživanju utvrđeno je da postoje razlike u roditeljskom odnosu i ponašanju prema djeci s obzirom na pol, a da je roditeljska podrška veoma važna za dječiji socio-emocionalni razvoj (Štironja Borić, et al. 2011). Prema drugim istraživanjima, slaba podrška, naročito majčina, može negativno uticati na dječije socio-emocionalno zdravlje i razvoj (Cooper, Masi, \& Vick, 2009). Da su stilovi roditeljskog ponašanja od velikog značaja za dječiji 
intelektualni i socijalni razvoj na predškolskom uzrastu, potvrđuju i drugi autori. Od topline emocionalnih odgovora roditelja na pitanja i zahtjeve njihovih predškolaca, bogatstva verbalnih poruka koje roditelji upućuju i njegovanja i kultivisanja dječijih interesovanja zavisi podrška ranom učenju u različitim aspektima razvoja (Landry $\mathrm{SH}, 2008)$.

Koliko je porodica važna u kreiranju sveukupnih uticaja na učenje i razvoj predškolske djece dokazano je i u brojnim drugim istraživanjima. U jednoj studiji prikazani su rezultati istraživanja koje je imalo za cilj da utvrdi uticaj ranih matematičkih iskustava stečenih u porodici na vještine početnog računanja u vrtiću. Testiranje djece u različitim aspektima razvoja vršeno je paralelno sa anketiranjem njihovih roditelja koji su odgovarali na pitanja o početnim matematičkim vještinama stečenim u porodici i o svojim očekivanjima. Rezultati studije pokazali su jedinstven doprinos roditelja dječijim matematičkim aktivnostima, kao i to da su roditeljska očekivanja od rane matematičke pismenosti odmah pored individualnih karakteristika djeteta (Kleemans, Peeters, Segers \& Verhoeven, 2012).

Kao jedan od najkrupnijih dometa razvoja na predškolskom uzrastu, mnogi autori navode razvoj govora i ovladavanje maternjim jezikom (Djačenko i Lavrentjeva, 1998; Tamis-LeMonda \& Rodriguez, 2009). Porodično okruženje je od presudnog značaja za razvoj i učenje govora, tvrde autori, a naročito su važna tri oblika porodične podrške ovom procesu. To su zajedničko učenje (čitanje literature, dnevne štampe i sl), kvalitet roditeljskog ponašanja i materijali za učenje (npr. igračke i knjige koje odgovaraju dječijem uzrastu). Porodične varijable koje mogu da utiču na kvalitet podrške učenju jezika u porodici su nivo obrazovanja roditelja i socio-ekonomski status; zato bi kreatori obrazovne politike trebalo da budu usmjereni na 
podršku porodicama i načinima na koje bi ona mogla da pomogne razvoj govora kod djece (Tamis-LeMonda \& Rodriguez, 2009). I Suzić (2010) smatra da je rani početak veoma važan za buduće akademske uspjehe i postignuća svakog pojedinca, a uspješnost tog starta, pored ostalog, zavisi i od porodice odnosno roditelja. Ovaj autor zaključuje da se bez uključivanja roditelja u proces ranog učenja ne mogu postići optimalni rezultati djeteta a na osnovu rezultata svog istraživanja zaključuje da je današnjim roditeljima potrebno bolje objasniti prirodu ranog početka i njihovu ulogu u ovom procesu.

Kada je reč o ovom pitanju, kao zaključak se može istaći da je jedan od najvećih izazova pred kojim se nalazi savremena porodica - kako pružiti adekvatnu podršku ranom učenju i razvoju djeteta u svim aspektima (Spasojević, 2011). Polazna osnova za pružanje podrške ranom učenju i razvoju djece u porodici morala bi biti: poznavanje osnovnih principa po kojima se dječiji razvoj odvija, zatim dobro poznavanje djeteta i procjena njegovih mogućnosti, te izbor igara i aktivnosti uz pomoć kojih će se najbrže postići razvojne promjene.

Odgovoran odnos prema sopstvenoj roditeljskoj ulozi trebalo bi da podrazumjeva aktivno bavljenje dječijim razvojem, blagovremeno uočavanje razvojnih promjena i poznavanje mogućnosti, interesovanja i talenata djeteta, jer se na taj način može odrediti sistem mjera i postupaka kojima će se uticati na osmišljavanje i tok ranog učenja (Cvjetković i Jeftović, 2014: 176).

U svrhu pružanja podrške ranom učenju i razvoju djeteta u porodici, neophodno je da roditelji pokažu viši nivo aspiracija za bavljenje razvojem djeteta, iako će to u velikoj mjeri zavisiti od kompetencija roditelja za bavljenje podrškom razvoju i metodike ranog učenja. Kompetentnost 
roditelja u ovoj oblasti obuhvata njihova interesovanja za dječiji razvoj, praćenje njegovog napretka i djelovanje ohrabrivanjem, pružanjem podrške i kreiranjem učećeg ambijenta u porodičnim uslovima.

\section{METOD}

\section{Ciljevi istraživanja}

S obzirom na činjenicu da je sve više nučnih studija usmjereno na proučavanje učenja i razvoja na predškolskom uzrastu, kao i na faktore koji utiču na ova dva procesa, izabrano je empirijsko istraživanje na uzorku roditelja predškolske djece s ciljem utvrđivanja njihovih stavova o ranom učenju. Očekivanje je da - uporedo sa porastom obrazovnog nivoa roditelja i razvojem drugačije „kulture življenja porodice“, te rastom tehnoloških mogućnosti neprestanog komuniciranja sa svijetom - dolazi i do drugačijeg odnosa roditelja prema ranom učenju, odnosno institucionalnom i vaninstitucionalnom učenju djece predškolskog uzrasta. Predmet istraživanja su stavovi roditelja predškolske djece o ranom učenju. Cilj istraživanja je identifikovati kakve stavove roditelji predškolske djece imaju o ovom procesu. Posebni ciljevi odnosili su se na utvrđivanje eventualnih razlika između stavova roditelja o ranom učenju u zavisnosti od sljedećih varijabli: pol roditelja, broj članova porodice, broj djece u porodici, redoslijed rođenja djeteta u porodici i nivo obrazovanja roditelja. U skladu sa postavljenim predmetom i posebnim ciljevima istraživanja, opšta hipoteza od koje se pošlo je da roditelji smatraju proces ranog učenja važnim za razvoj i napredovanje njihove djece, što je stanovište i brojnih postojećih naučnih studija. Kada su u pitanju pothipoteze istraživanja, pretpostavka je da postoje statistički značajne razlike u stavovima roditelja o ranom učenju u zavisnosti od pola 
roditelja, broja članova porodice, broja djece u porodici, redoslijeda rođenja djeteta u porodici i nivoa obrazovanja roditelja.

\section{Varijable i instrument istraživanja}

Istraživanje je zasnovano na primjeni deskriptivne metode, anketiranja kao istraživačke tehnike i anketnog upitnika kao osnovnog instrumenta istraživanja. Upitnik se sastoji iz dva dijela: inventara za prikupljanje osnovnih socio-demografskih podataka o ispitanicima i prilagođene verzije skalera Stavovi roditelja predškolske djece o ranom učenju (PRORU) koji je ranije korišten u istraživanju autorki Cvjetković i Jeftović (2014). Petostepeni skaler PRORU sastoji se od 23 ajtema i namijenjen je otkrivanju stavova roditelja o ranom učenju, sa jasnim očekivanjem da su oni značajni za izbor roditeljskog stila pri uključivanju u ovaj proces. Ajtemi su formulisani u vidu stavova koji afirmativno govore o ranom učenju (npr. Vjerujem da u igri djeca mogu dosta da nauče; Predškolska djeca mogu da uče i u porodici i u vrtiću; Putem učenja predškolska djeca mogu da postignu više nego što se od njih očekuje na tom uzrastu; Rano učenje je moguće i poželjno jer se njime postavljaju temelji ukupnog razvoja ličnosti itd); zatim, u vidu stavova koji govore o predškolskom uzrastu kao najpogodnijem periodu za učenje (npr. Slažem se sa narodnom izrekom „Drvo se savija dok je mlado“, što znači da i djeca treba da počnu sa učenjem što ranije; Svako predškolsko dijete je drugačije i uči na svoj jedinstven način, u skladu sa onim čemu je ono doraslo; Rano učenje ima smisla samo ako predškolska djeca slobodno učestvuju u njemu i pri tome se osjećaju zadovoljnim itd). Određeni broj ajtema govori o ulozi roditelja u procesu ranog učenja (npr. Od roditelja najviše zavisi kakve će 
stavove predškolska djeca imati prema učenju; Predškolska djeca uče od odraslih, ali i od vršnjaka i druge djece, koristeći njihova iskustva itd). Ostatak ajtema u skaleru formulisan je u vidu stavova koji negativno govore o ranom učenju (npr. Ne vjerujem da će se ulaganje u predškolsko učenje isplatiti boljim i većim postignućima djeteta u kasnijem razvoju; Najbitnije je da roditelji obezbijede bezbrižno djetinjstvo svojoj djeci, jer ih, kada odrastu, svakako očekuje škola, učenje i mnogo drugih problema; Djeca treba da počnu sa učenjem tek kada krenu u školu, a do tada samo da se igraju itd). Stavovi roditelja su važni i zbog formiranja njihovog odnosa prema djetinjstvu uopšte i povjerenja u mogućnosti i opravdanost ranog učenja koje je usmjereno ka namjernom izazivanju promjena u razvoju. Pouzdanost kao mjerna karakteristika skalera utvrđena je izračunavanjem Kronbahovog Alfa koeficijenta, čija je vrijednost iznosila 0,71. Time je potvrđeno da je instrument pouzdan izvor saznanja o bazičnim stavovima roditelja o ranom učenju, te da ima prihvatljivu pouzdanost.

Nezavisnu varijablu $\mathrm{u}$ istraživanju čine sljedeća obilježja roditelja predškolske djece: pol roditelja (muški ili ženski), broj članova porodice (tri, četiri, pet, više od pet), broj djece u porodici (jedno, dvoje, troje, četvoro ili više), redoslijed rođenja djeteta u porodici (prvo dijete, drugo dijete, treće dijete, četvrto i ostala djeca) i nivo obrazovanja roditelja (osnovna škola, srednja škola, viša škola, fakultet, magistar/master ili doktor nauka). Zavisnu varijablu čine stavovi roditelja predškolske djece o ranom učenju.

\section{Uzorak i procedura istraživanja}

Populaciju u istraživanju činili su svi roditelji čija su predškolska djeca uzrasta od tri do šest godina pohađala javne i privatne vrtiće u Istočnom dijelu Republike Srpske i Brčko Distriktu, a uzorak je odabran postupkom 
jednostavnog slučajnog izbora. U istraživanju je učestovalo 150 roditelja i to 45 očeva i 105 majki. Od ukupnog uzorka, 34 roditelja bila su iz porodica koje broje tri člana, 84 roditelja iz čertvoročlanih porodica, 23 roditelja iz petočlanih porodica i 9 roditelja iz porodica sa 5 ili više članova. S ozirom na broj djece u porodici, struktura uzorka je sljedeća: 41 roditelj sa jednim djetetom u porodici, 82 roditelja sa dvoje djece, 21 roditelj sa troje djece i 6 roditelja sa četvoro ili više djece. Prema redoslijedu rođenja djeteta $u$ porodici, u istraživanju je učestvovalo 88 roditelja čije prvo dijete pohađa vrtić, 51 roditelj čije drugo dijete pohađa vrtić, 8 roditelja čije treće dijete pohađa vrtić i 3 roditelja čije četvrto dijete pohađa vrtić. Prema obrazovnoj strukturi, uzorak čine 55 roditelja sa završenom srednjom školom, 9 roditelja sa završenom višom školom, 73 roditelja sa završenim fakultetom i 13 roditelja sa završenim magistarskim/master ili doktorskim studijem. Istraživanje je realizovano u januaru i februaru 2016. godine na uzorku roditelja predškolske djece koja pohađaju vrtiće u sljedećim gradovima: Bijeljina, Zvornik i Brčko Distrikt.

\section{Postupci za statističku obradu podataka}

$\mathrm{Za}$ statističku obradu podataka, pored izračunavanja osnovnih deskriptivnih statistika, korišteni su i $t$-test nezavisnih uzoraka i jednofaktorska analiza varijanse s naknadnim poređenjem (ANOVA).

\section{REZULTATI}

Rezutati istraživanja o međuzavisnosti ličnih obilježja roditelja i njihovih stavova o ranom učenju prikazani su u nastavku rada za svako obilježje pojedinačno. 
Pol roditelja

Rezultati istraživanja o međuzavisnosti pola roditelja i njihovih stavova o ranom učenju prikazani su prema podacima dobijenim poređenjem srednjih vrijednosti $t$-testom nezavisnih uzoraka.

Tabela 1: Razlika u stavovima o ranom učenju u odnosu na pol roditelja

\begin{tabular}{ccccccc}
\hline Pol roditelja & $\mathbf{N}$ & $\mathbf{M}$ & $\mathbf{S D}$ & $\mathbf{t}$ & $\mathbf{d f}$ & $\mathbf{p}$ \\
\cline { 1 - 4 } muški & 45 & 90,18 & 8,74 & & & \\
\cline { 1 - 5 } & 105 & 88,77 & 6,72 & 0,96 & 134 & 0,33 \\
\hline
\end{tabular}

U Tabeli 1 prikazani su podaci o broju, srednjim vrijednostima i standardnoj devijaciji grupa roditelja muškog i ženskog pola. Srednja vrijednost roditelja muškog pola (M) iznosi 90,18 pri standardnom odstupanju (SD) 8,74, dok ona kod roditelja ženskog pola iznosi 88,77 pri standardnom odstupanju (SD) 6,72. Nivo značajnosti p jeste $>0,05(0,33)$, što znači da ne postoji statistički značajna razlika između srednjih vrijednosti u stavovima o ranom učenju majki i očeva. Prema navedenim statističkim pokazateljima, uočljivo je da su očevi u svojim stavovima iskazali veće povjerenje u mogućnosti ranog učenja, ali ne možemo govoriti i o značajno drugačijim stavovima u odnosu na majke, jer dobijena razlika nije dostigla nivo statističke značajnosti. Ovaj rezultat razlikuje se od rezultata dobijenih u drugim, sličnim istraživanjima (Cooper, Masi, \& Vick, 2009; Štironja Borić, et al. 2011). 


\section{Broj članova porodice}

Jednofaktorskom ANOVA analizom ispitivan je uticaj varijable brojnost odnosno broj članova porodice na stavove roditelja predškolske djece o ranom učenju. Rezultati ovog istraživanja prikazani su u Tabeli 2.

Tabela 2: Razlika u stavovima o ranom učenju u odnosu na broj članova porodice

\begin{tabular}{|c|c|c|c|c|c|c|}
\hline $\begin{array}{c}\text { Varijabla: } \\
\text { Broj članova porodice }\end{array}$ & $\mathbf{N}$ & M & SD & $\mathbf{F}$ & $\mathbf{p}$ & $\eta 2$ \\
\hline Tri & 34 & 90,70 & 7,99 & \multirow{4}{*}{0,83} & \multirow{4}{*}{0,47} & \multirow{4}{*}{0,01} \\
\hline Četiri & 84 & 88,48 & 7,19 & & & \\
\hline Pet & 23 & 89,00 & 7,44 & & & \\
\hline Više od pet & 9 & 90,55 & 6,67 & & & \\
\hline
\end{tabular}

Dobijeni statistički pokazatelji $(\mathrm{F}=0,83 ; \mathrm{p}=0,47 ; \eta 2=0,01)$ svjedoče da ne postoji statistički značajna razlika u stavovima roditelja o ranom učenju u zavisnosti od broja članova porodice (vidi Tabelu 2). Ovim je potvrđeno da roditelji iz porodica sa tri, četiri, pet i više od pet članova približno jednako percipiraju da je predškolsko doba najbolje vrijeme za učenje, kako u porodici tako i u vrtićima, sa čim su saglasni i brojni teoretičari (Kamenov i Spasojević, 2008; Spasojević, Jeftović i Cvjetković, 2013).

\section{Broj djece u porodici}

Broj djece u porodici može determinisati stavove roditelja o važnim pitanjima, kao što je, prije svega, rano učenje, zbog bitno različitih iskustava $\mathrm{u}$ roditeljstvu. Rezultati istraživanja o uticaju broja djece u porodici na stavove roditelja predškolske djece o ranom učenju prikazani su prema podacima dobijenim jednofaktorskom univarijantnom ANOVA analizom s naknadnim poređenjem. 
Tabela 3: Razlika u stavovima o ranom učenju u odnosu na broj djece $u$ porodici

$\begin{array}{lllllll}\text { Varijabla: } & \text { N } & \text { M } & \text { SD } & \text { F } & \text { p } & \boldsymbol{\eta} 2\end{array}$

Broj djece u porodici

\begin{tabular}{|c|c|c|c|c|c|c|}
\hline Jedno & 41 & 89,12 & 8,328 & \multirow{4}{*}{0,84} & \multirow{4}{*}{0,47} & \multirow{4}{*}{0,01} \\
\hline Dvoje & 82 & 88,70 & 6,961 & & & \\
\hline Troje & 21 & 90,04 & 7,55 & & & \\
\hline Četvoro ili više & 6 & 93,33 & 5,27 & & & \\
\hline
\end{tabular}

Kao što je prikazano u Tabeli 3 , vrijednost $F$-testa $(F=0,84)$ nije statistički značajna $(\mathrm{p}=0,47)$ i $(\eta 2=0,01)$; stoga možemo zaključiti da ne postoji statistički značajna razlika u stavovima roditelja o ranom učenju u zavisnosti od broja djece u porodici. Dobijeni rezultat razlikuje se od rezultata istraživanja (Štironja Borić, et al. 2011) u kojem je utvrđeno da je broj djece u porodici važan prediktor roditeljskog pozivitnog ili negativnog ponašanja prema djeci.

\section{Redoslijed rođenja djeteta u porodici}

Primjenom jednofaktorske univarijantne ANOVA analize $\mathrm{s}$ naknadnim poređenjem, istražili smo uticaj redoslijeda rođenja djeteta $u$ porodici na stavove roditelja predškolske djece o ranom učenju. Dobijeni podaci prikazani su u Tabeli 4 .

Vrijednost F-testa $(\mathrm{F}=0,75)$, uz ostale statističke pokazatelje $(\mathrm{p}=0,52)$ i $(\eta 2=0,02)$, statistički nije značajna (vidi Tabelu 4). To potvrđuje da ne postoji statistički značajna razlika u stavovima roditelja predškolske djece o ranom učenju u zavisnosti od redoslijeda rođenja djeteta koje pohađa vrtić. Dakle, na ispitivanom uzorku roditelja utvrđeno je da - bez obzira na redoslijed rođenja djeteta koje trenutno pohađa vrtić - roditelji sa malim međusobnim razlikama, koje nisu statistički značajne, percipiraju važna 
pitanja o ranom učenju kao što su: uloga roditelja u ovom procesu, učenje djeteta u porodici i okruženju, učenje uz pomoć vršnjaka i odraslih, koristi od ranog učenja itd. Ulogu roditelja u ranom učenju naglašava i veliki broj naučnika (Tamis-LeMonda \& Rodriguez, 2009; Suzić, 2010).

Tabela 4: Razlika u stavovima o ranom učenju u odnosu na redoslijed rođenja djeteta u porodici

Varijabla:

$\begin{array}{lllllll}\text { Redoslijed rođenja djeteta } u & \text { N } & M & \text { SD } & \text { F } & \text { p } & \eta 2\end{array}$ porodici

\begin{tabular}{|c|c|c|c|c|c|c|}
\hline Prvo dijete & 88 & 89,26 & 7,42 & \multirow{4}{*}{0,75} & \multirow{4}{*}{0,52} & \multirow{4}{*}{0,02} \\
\hline Drugo dijete & 51 & 89,56 & 7,47 & & & \\
\hline Treće dijete & 8 & 85,50 & 7,55 & & & \\
\hline Četvrto i ostala djeca & 3 & 90,66 & 2,30 & & & \\
\hline
\end{tabular}

Nivo obrazovanja roditelja

$\mathrm{U}$ istraživanju je ispitivan i uticaj nivoa obrazovanja roditelja predškolske djece na njihove stavove o ranom učenju. Rezultati testiranja pomenutog uticaja jednofaktorskom univarijantnom ANOVA analizom $\mathrm{s}$ naknadnim poređenjem prikazani su u Tabeli 5.

Tabela 5: Razlika u stavovima o ranom učenju u odnosu na nivo obrazovanja roditelja

\begin{tabular}{|c|c|c|c|c|c|c|}
\hline $\begin{array}{c}\text { Varijabla: } \\
\text { Nivo obrazovanja roditelja }\end{array}$ & $\mathbf{N}$ & $\mathbf{M}$ & SD & $\mathbf{F}$ & p & $\eta 2$ \\
\hline Srednja škola & 55 & 89,34 & 7,071 & \multirow{4}{*}{1,49} & \multirow{4}{*}{0,21} & \multirow{4}{*}{0,02} \\
\hline Viša škola & 9 & 90,66 & 4,82 & & & \\
\hline Fakultet & 73 & 88,27 & 7,63 & & & \\
\hline $\begin{array}{c}\text { Magistar/master ili doktor } \\
\text { nauka }\end{array}$ & 13 & 92,69 & 8,13 & & & \\
\hline
\end{tabular}


Analiza varijanse sa jednim faktorom pokazala je da ne postoje statistički značajne razlike u stavovima roditelja predškolske djece o ranom učenju u zavisnosti od njihovog nivoa obrazovanja $(\mathrm{F}=1,49 ; \mathrm{P}=0,21 ; \eta 2$ $=0,02$ ). Sudeći prema Koenovom kriterijumu, ukupni efekat razlika između grupa spada u efekte male veličine a dobijene razlike nisu statistički značajne (Cohen, 1998).

\section{DISKUSIJA}

Iako je naše polazno očekivanje bilo da se roditelji razlikuju u stavovima o ranom učenju u zavisnosti od pola, uzevši u obzir da majke, prema tradicionalnoj podjeli uloga koja je karakteristična i za naše društvo, više vremena provode sa svojom djecom (samim tim se očekuje da imaju drugačije, više zaštitničke, stavove o ranom učenju), ono se nije pokazalo tačnim na ispitivanom uzorku roditelja. Drugim riječima, roditelji bez obzira na pol imaju ujednačena stanovišta o mogućnostima ranog učenja. Objašnjenje za ovu tendenciju moglo bi se potražiti u povoljnijoj humanizaciji odnosa među supružnicima i napuštanju klasične podjele na muške $\mathrm{i}$ ženske poslove, pri čemu je vaspitanje i briga o dječijem razvoju i učenju ženski posao, što je jedna od karakteristika savremene porodice, što se navodi i u literaturi (Spasojević, 2011). Kad govorimo o istom pitanju - a iz perspektive roditelja - odnosno o mogućnostima njihovog direktnog uključivanja $\mathrm{u}$ proces ranog učenja zasnovanog na naučnim osnovama o učenju i razvoju „u običnom životu“, roditelji sebe često smatraju nekompetentnim, što je utvrđeno i u drugim istraživanjima (Suzić, 2010). Nerijetko se i povlače u ovom procesu pa je njihovo djelovanje više usmjereno intuitivnim pedagoškim idejama ili osobinama ličnosti koje bitno 
djeluju na stil roditeljstva. Rijetki su roditelji koji svoju ulogu optimalno podređuju potrebama djelovanja na razvoj djeteta.

Polazno očekivanje da će se roditelji predškolske djece iz višečlanih i porodica sa manjim brojem članova razlikovati u stavovima o ranom učenju osporeno je na ispitivanom uzorku. Ovo svjedoči i o kulturološkom obilježju porodice: da se na djecu u pogledu očekivanja gleda uravnoteženo, da porodica nije uvjerena da „rani polazak“ ima neke prednosti u odnosu na uobičajeni polazak u školu sa sedam godina. Međutim, ovaj rezultat može se dovesti i u vezu sa još uvijek dominantnim uticajem okruženja na formiranje mišljenja roditelja o ranom učenju. U tom slučaju, drugi članovi porodice, njihovi stavovi i iskustvo nisu od presudnog značaja za formiranje mišljenja roditelja o ranom učenju, već je ono još uvijek pod snažnim uticajem tradicionalnih pogleda i shvatanja sredine.

Istraživanje je započeto uz uvjerenje da će se roditelji predškolske djece koji imaju više djece $u$ porodici značajno razlikovati u svojim stavovima o ranom učenju od roditelja čije porodice broje manje djece, ali ono se nije pokazalo tačnim. Dakle, mišljenja i stavovi roditelja o ranom učenju, odnosno učenju na predškolskom uzrastu, nisu pod bitnim dejstvom varijable kakva je broj djece u porodici, što je skoro podudarno sa rezultatima dobijenim u slučaju varijable broj članova porodice. Ovim je osporena i pretpostavka, ili predrasuda zaživjela u pedagoškoj praksi, da će porodično vaspitanje biti povoljnije ukoliko ima više djece u porodici. Budući da je riječ o vrlo složenim odnosima u porodicama sa više djece, ovaj rezultat treba uzeti sa rezervom, a, u svakom slučaju, on predstavlja ozbiljan izazov za dalja pedagoška i psihološka istraživanja. Vjerovatno se taj uticaj daleko više 
ispoljava u interakciji među djecom u porodici, dok roditelji ne razdvajaju djecu na mlađu i stariju.

Inicijalni stav i očekivanje da će se roditelji predškolske djece razlikovati u stavovima o ranom učenju na osnovu posjedovanja ili nedostatka prethodnog iskustva sa djecom u porodici - nije se pokazalo tačnim. Na odabranom uzorku ispitanika procjene roditelja o ranom učenju ne zavise od ovog socio-demografskog obilježja i ne mogu se dovesti u vezu.

Rezultati ovog istraživanja pokazali su da su roditelji u našem društvu jednako opredijeljeni prema ranom učenju bez obzira na njihov nivo obrazovanja. Suptilnijom analizom ovog rezultata, može se doći do zaključka da se na završnim stepenima obrazovanja mladi ne pripremaju za roditeljstvo kao važnu životnu funkciju, te da su malo upoznati sa najnovijim naučnim pogledima na mogućnosti ranog djetinjstva i ranog učenja. To potvrđuju i rezultati drugih istraživanja koji su ukazali na raširene predrasude roditelja o najboljem vremenu za početak učenja, na njihovo nepovjerenje u rano učenje, kao i sopstvenu ulogu u ovom procesu. Osim toga, roditelji ne uviđaju efekte i koristi od ranog učenja na koje upozoravaju naučnici (Cvjetković i Jeftović, 2014). Prema drugim studijama, odgovoran odnos roditelja prema ranom učenju povezan je sa stilovima roditeljskog ponašanja (Landry, 2008) a ne prioritetno sa obrazvonim nivoom roditelja.

\section{ZAKLJUČCI}

Da je porodica važan faktor u procesu ranog učenja i razvoja djeteta dokazuje i činjenica da se ova institucija ne potcjenjuje u literaturi novijeg datuma niti razvojnim dokumentima i strategijama obrazovanja. Kada su u pitanju rezultati našeg istraživanja, oni upućuju na nekoliko važnih zaključaka i pedagoških implikacija. 
- Razlike u stavovima roditelja predškolske djece koja pohađaju vrtić o ranom učenju s aspekta pola, broja članova porodice, broja djece $\mathrm{u}$ porodici, redoslijeda rođenja djeteta u porodici i nivoa obrazovanja roditelja nisu statistički značajne na našem uzorku ispitanika. Ovim nije potvrđena hipoteza o postojanju razlika u stavovima roditelja predškolske djece o ranom učenju u zavisnosti od navedenih sociodemografskih obilježja ispitanika. Od roditelja koji su svoju djecu uključili u programe predškolskog učenja očekuju se povoljniji stavovi o ranom učenju (u odnosu na ostatak populacije roditelja čija djeca ne pohađaju vrtić), te uočavanje njegovog značaja i uloge $u$ procesu cjeloživotnog učenja; stoga dobijeni rezultat predstavlja ohrabrujuće saznanje jer roditelji bez značajnih međusobnih razlika procjenjuju ovaj važan proces u životu njihove djece.

- Ujednačeni stavovi o ranom učenju na uzorku roditelja čija djeca pohađaju vrtić mogu biti posljedica uključenosti roditelja u različite oblike partnerstva koje vrtić realizuje sa porodicom. Ciljevi tog partnerstva usmjereni su na bolje razumijevanje ranog i predškolskog djetinjstva i ranog učenja u porodici i institucijama, a realizuju se $u$ vidu radionica, roditeljskih sastanaka, individualnih razgovora i sl. U vezi s tim, važno je da se postojeći programi rada sa roditeljima nastave $\mathrm{i}$ da se novi roditelji priključuju jer to može biti od koristi naročito $\mathrm{u}$ pogledu objektivne procjene i spremnosti roditelja da mijenjaju svoja mišljenja i odnos prema ranom učenju ka povoljnijem.

- Generalno, u društvu je neophodno ispitati stavove roditelja čija djeca ne pohađaju programe predškolskog vaspitanja i obrazovanja, a koji 
su procentualno zastupljeniji na teritoriji naše zemlje. U skladu sa dobijenim rezultatima, treba ih uključiti u neke od programa rada sa roditeljima.

- Rezultati istraživanja upućuju na zaključak da znanja o ranom učenju treba ugraditi unutar obrazovnog sistema i bitno drugačije ih tretirati, bez obzira na struku i usmjerenje roditelja, kao jedan od ozbiljnijih problema važnih za životni kontekst, za pogled na budućnost i pripremu mladih ljudi za roditeljstvo. Time bi se uticalo da budući roditelji, umjesto gledanja na predškolsko dijete kao „nemoćno biće“ kome će za odrastanje biti dovoljno obezbjeđivanje adekvatnih egzistencijalnih uslova, shvate značaj ovog „kritičnog perioda“ u životu čovjeka. U ranom i predškolskom djetinjstvu najbitnije je kreiranje povoljnog okruženja za rano učenje i stimulaciju moždanih struktura i CNS, na šta upozorava i naučna javnost (Rajović, 2010; Vonta, 2009).

- Sistematsko osvješćivanje roditelja i šire javnosti o potrebi, značaju i mogućnostima ranog učenja važno je da bi se „razbile“ uobičajene predrasude da je rano učenje manje važno od onog u školskoj dobi, odnosno da bi se ublažile njihove nevjerice da je na predškolskom uzrastu učenje uopšte opravdano jer „djeca treba da se igraju“. Ovo su potvrdile i druge studije čiji je zaključak da je uključivanje roditelja u programe učenja važno za poboljšanje njihovih roditeljskih kompetencija (Ansari \& Gershoff, 2016), što je svakako važno i za izgradnju stavova o ranom učenju. 


\title{
ATTITUDES OF PARENTS OF PRESCHOOL CHILDREN ABOUT EARLY LEARNING
}

\begin{abstract}
Bearing in mind a pedagogical significance of the influence of environment on the growth and development of children in early childhood, the family and institutions of pre-school education are the most often mentioned as key factors. In this paper, the authors deal more with the family impact, since prejudices and stereotypes about early learning opportunities are often seen among parents. Parents "distrust" the "power" of action on the growth and development by early learning, which can be influenced by various socio-demographic variables, a culture marked by traditionalism, and the inheritance of cultural patterns of the family from the past. In order to determine the parents' attitude to early learning, we conducted a research on the sample of 150 parents whose children attended kindergarten, to identify their assessments on this issue. The applied methodology was related to the discovery of differences in parents' estimates on early learning with regard to some of their socio-demographic characteristics which were under the strong influence of the cultural program of the environment. The research results showed that differences in the estimation of parents of preschool children about early learning from the aspect of gender, the number of family members, the number of children in the family, the order of birth of the child in the family, and the level of parents' education, are not statistically significant on the test sample. The research results show important pedagogical implications which are presented in the paper.
\end{abstract}

KEY WORDS: early learning, parents' attitudes, pedagogical implications. 


\section{REFERENCE}

Ansari, A., \& Gershoff, E. (2016). Parent Involvement in Head Start and Children's Development: Indirect Effects Through Parenting. Journal of Marriage and the Family, 78(2), 562-579. Available at: http://doi.org/10.1111/jomf.12266. Accessed [10. 3. 2017].

Berris, R., \& Miller, E. (2011). How design of the physical environment impacts early learning: Educators and parents perspectives. Australasian Journal of Early Childhood, 36(2),1-17.

Cooper, J. L., Masi, R. \& Vick, J. (2009). Social-emotional Development in Early Childhood What Every Policymaker Should Know. The National Center for Children in Poverty.

Cohen, J. (1988). Statistical power analysis for the behavioral sciences (2nd ed.). Hillsdale, NJ: Lawrence Earlbaum Associates.

Cvjetković, M. i Jeftović. M. (2014). Vjeruju li roditelji u moć i koristi od ranog učenja? U Zborniku ,Savremene paradigme u nauci i naučnoj fantastici“ (171-185). Niš: Filozofski fakultet.

Djačenko, O. M. i Lavrentjeva, T. V. (1998). Psihički razvoj predškolske dece. Beograd: Zavod za udžbenike i nastavna sredstva.

Drummond J. Parent support programs and early childhood development: Comments on Goodson, and Trivette and Dunst. In: Tremblay RE, Barr RG, Peters RDeV, eds. Encyclopedia on Early Childhood Development [online]. Montreal, Quebec: Centre of Excellence for Early Childhood Development; 2005:1-6. Available at: http://www.childencyclopedia.com/documents/DrummondANGxp.pdf. Accessed [17. 2. 2017]. 
Kamenov, E. i Spasojević, P. (2008). Predškolska pedagogija. Bijeljina: Pedagoški fakultet.

Kleemans, M. A. J., Peeters, M. H. J., Segers, P. C. J., \& Verhoeven, L. T. W. (2012). Child and home predictors of early numeracy skills in kindergarten. Early Childhood Research Quarterly, 27(3), 471-477.

Landry SH. The role of parents in early childhood learning. In: Tremblay RE, Barr RG, Peters RDeV, Boivin M, eds. Encyclopedia on Early Childhood Development [online]. Montreal, Quebec: Centre of Excellence for Early Childhood Development; 2008:1-6. Available at: http://www.child-encyclopedia.com/documents/LandryANGxp.pdf. Accessed [21. 2. 2017].

Rajović, R. (2010). NTC sistem učenja metodički priručnik za vaspitače. Vršac: Visoka škola za obrazovanje vaspitača „Mihailo Pavlov“.

Spasojević, P. (2011). Porodična pedagogija i odgovorno roditeljstvo. Laktaši: Nova škola plus i Bijeljina: Pedagoški fakultet.

Spasojević, P., Jeftović, M. i Cvjetković, M. (2013). Rano učenje kao najaktuelniji izazov savremene pedagogije. U Zborniku „Nauka $i$ tradicija“ (597-612). Pale: Filozofski fakultet.

Strategija razvoja obrazovanja Republike Srpske za period 2016-2021. godine. (2016). Banja Luka: Ministarstvo prosvjete i kulture Republike Srpske. Preuzeto 9. 11. 2017. sa stranice http://www.atvbl.com/wp-content/uploads/2016/03/Prijedlogstrategije-razvoja-obrazovanja-RS-2016-2021-1.pdf

Suzić, N. (2010). Akademska budućnost zavisi od ranog starta. Nova škola, časopis za teoriju i praksu savremene škole i predškolstva, (7), 160175. 
Tamis-LeMonda CS., \& Rodriguez ET. Parents' role in fostering young children's learning and language development. Rev ed. In: Tremblay RE, Barr RG, Peters RDeV, Boivin M, eds. Encyclopedia on Early Childhood Development [online]. Montreal, Quebec: Centre of Excellence for Early Childhood Development; 2009:1-9. Available at: http://www.child-encyclopedia.com/documents/Tamis-LeMondaRodriguezANGxp_rev-Parenting.pdf. Accessed [5. 3. 2017].

Vonta, T. (2009). Organizirana predšolska vzgoja v izzivih družbenih sprememb. Ljubljana: Pedagoški institut.

Štironja Borić, A., Roščić, S., Sedmak M., Šepčević, A., \& Keresteš G. (2011). Social centextual determinants of parental behaviour of preschool children's mothers and fathers. Croatian Journal of Education, (3), 25-55. 